\title{
Peningkatan kemampuan keaksaraan awal melalui permainan kartu angka pada anak kelompok A di TK Negeri Pembina Bantul
}

\author{
Sri Sumarsih \\ TK Negeri Pembina Bantul Yogyakarta \\ J1. Parangtritis Km 8.5 Tembi Timbulharjo Sewon Bantul Yogyakarta Indonesia \\ E-mail: sumarsihsri14@gmail.com
}

\begin{tabular}{ll}
\hline \hline ARTICLE INFO & ABSTRACT \\
\hline Article history: & Mengenal keaksaraan awal menjadi kemampuan dasar yang perlu distimulasi \\
Revised: $03-05-2020$ & sejak dini. Penelitian ini bertujuan untuk meningkatkan kemampuan keaksaraan \\
Accepted: $10-06-2020$ & awal melalui permainan kartu angka pada anak kelompok A di TK Negeri \\
& Pembina Bantul. Penelitian ini merupakan penelitian tindakan kelas. Adapun \\
Keywords: & subjek penelitian sejumlah 20 anak, yang terdiri dari 5 anak laki-laki dan 15 anak \\
kemampuan, keaksaraan & perempuan. Metode pengumpulan data menggunakan observasi, dengan \\
awal, kartu angka, anak & instrumen pengumpulan data berupa lembar observasi. Kriteria keberhasilan \\
& dalam penelitian ini adalah apabila minimal 76 \% anak sudah mencapai BSH \\
& (Berkembang Sesuai Harapan) ataupun BSB (Berkembang Sangat Baik). \\
& Adapun teknik analisis data menggunakan analisis data kuantitatif dan kualitatif. \\
& Hasil penelitian menunjukkan bahwa kemampuan mengenal keaksaraan awal \\
& dapat ditingkatkan melalui permainan kartu angka. Hal ini ditunjukkan pada \\
& jumlah anak yang berada pada kriteria Berkembang Sesuai Harapan (BSH) dan \\
& Berkembang Sangat Baik (BSB) mengalami peningkatan 57,89 \%. Adapun \\
& langkah-langkahnya yaitu: guru menyiapkan kartu angka dan lembar kegiatan \\
& anak, anak mengambil lembar kegiatan dan kartu angka, anak bermain kartu \\
angka dengan memilih dan menghubungkan gambar yang ada dalam lembar \\
kegiatan dengan lambang bilangannya, dan anak mengkomunikasikan hasil \\
menghubungkan gambar dengan kartu angka pada guru.
\end{tabular}

Getting to know early literacy is a basic ability that needs to be stimulated early on. This study aims to improve the ability to recognize early literacy through numeric card games in group A children in TK Negeri Pembina Bantul. This research is a classroom action research. The research subjects were 20 children, consisting of 5 boys and 15 girls. The data collection method uses observation, with data collection instruments in the form of observation sheets. The criterion for success in this study is if a minimum of $76 \%$ of children have reached BSH (Developed as Expected) or BSB (Developed Very Good). The data analysis technique uses quantitative and qualitative data analysis. The results showed that the ability to recognize early literacy can be improved through the numbers card game. This is shown in the number of children who are in the criteria of Developing in Accordance with Expectations (BSH) and Very Good Development (BSB) experiencing an increase of 57.89\%. The steps are: the teacher prepares a number card and activity sheet for the child, the child takes the activity sheet and number card, the child plays the number card by selecting and connecting the picture in the activity sheet with the symbol of the number, and the child communicates the results of connecting the picture to the number card to the teacher. 


\section{PENDAHULUAN}

Memasuki abad ke-21, tatanan kehidupan di seluruh aspek berubah dengan sangat cepat setiap harinya. Warga dunia dituntut untuk menguasai berbagai kecakapan hidup agar dapat menghadapi dinamika tersebut. Kecakapan hidup tersebut selanjutnya disebut dengan literasi. Terdapat beberapa literasi yang harus ditanamkan sejak dini melalui pendidikan formal, diantaranya literasi baca tulis dan literasi numerasi. Di Indonesia, penguasaan kedua literasi tersebut pada usia dini terselenggara melalui pembelajaran lambang bilangan. Yulaelawati (2016) menyatakan bahwa lambang bilangan merupakan tatanan fondasi untuk menguasai kemampuan membaca, menulis, dan berhitung yang menyenangkan.

Pendidikan Anak Usia Dini (PAUD) dalam UU Nomor 20 tahun 2003 tentang Sistem Pendidikan Nasional pasal 1 bertujuan untuk mengoptimalkan pertumbuhan dan perkembangan peserta didik dalam rangka mempersiapkan pendidikan di jenjang berikutnya. Dalam pasal 28, dinyatakan bahwa bentuk PAUD pada jalur formal meliputi Taman Kanak-kanak (TK), Raudhatul Athfal (RA), atau bentuk lain yang sederajat. Di Indonesia, peserta didik TK dikelompokkan menjadi dua kelompok berdasarkan usia, yaitu kelompok A untuk usia 4-5 tahun dan kelompok B untuk usia 5-6 tahun. Peserta didik TK dalam rentang usia 4-6 tahun berada dalam masa emas (golden age) yang memiliki potensi perkembangan optimal dalam segala aspek, meliputi aspek nilai agama dan moral, aspek fisik motorik, aspek kognitif, aspek bahasa, aspek sosial emosional, serta aspek seni (Suryana, 2016: p 36).

Perkembangan kognitif menjadi salah satu perkembangan yang penting distimulasi sejak dini. Pengenalan lambang bilangan pada anak termasuk bagian dari perkembangan kognitif yang dapat dilejitkan pada masa emas ini. Pembelajaran lambang bilangan pada jenjang TK terintegrasi dalam program pengembangan bahasa khususnya pada Kompetensi Dasar 3.12 (mengenal lambang bilangan melalui bermain) dan 4.12 (menunjukkan kemampuan lambang bilangan dalam berbagai bentuk karya). Kompetensi lambang bilangan tersebut diindikasikan dengan kemampuan menghubungkan benda-benda konkrit dengan lambang bilangan 1-10.

Pada kenyataannya, capaian kompetensi lambang bilangan kelompok A TK Negeri Pembina Bantul pada semester II tahun ajaran 2018/2019 belum optimal. Hal ini dapat dilihat dari 20 peserta didik, hanya $25 \%$ yang sudah mengenal lambang bilangan 1-10. Padahal, pengenalan lambang bilangan diperlukan anak sebagai bekal dasar dalam kehidupan sehari-hari. Rendahnya capaian kompetensi tersebut tidak terlepas dari keterbatasan media pembelajaran yang sesuai. TK Negeri Pembina Bantul belum memiliki media pembelajaran yang dapat menstimulasi pengenalan lambang bilangan 1-10 dengan optimal. Mursid (2015: p 47) menyatakan bahwa beberapa hal yang perlu dipertimbangkan dalam menentukan media pembelajaran tersebut antara lain: tujuan instruksional pembelajaran, efektivitas, dan karakteristik peserta didik.

Untuk meningkatkan kemampuan anak dalam mengenal keaksaraan awal khususnya lambang bilangan, peneliti akan menggunakan kartu angka. Kartu angka merupakan media pembelajaran yang sesuai untuk meningkatkan kemampuan pengenalan lambang bilangan 1-10 pada anak kelompok A yang dilakukan melalui permainan. Belajar sambil bermain merupakan metode yang sesuai dengan karakteristik anak TK. Bermain memberikan kesempatan pada anak untuk mengekspresikan kreativitasnya untuk menemukan suatu pengalaman belajar yang baru. Oleh karena itu, peneliti ingin meningkatkan kemampuan pengenalan lambang bilangan 1-10 melalui permainan kartu angka.

Kartu angka merupakan kartu yang bertuliskan angka sesuai tema yang diajarkan. Beberapa manfaat dari kartu angka yaitu: 1) melatih kemampuan berhitung, 2) melatih kemampuan membedakan warna, 3) melatih kemampuan membedakan angka, 4) melatih mental, dan 5) melatih motorik tangan. Permainan kartu angka diharapkan dapat meningkatkan atensi dan konsentrasi peserta didik karena disertai dengan gambar yang menarik dan konkret sesuai tema pembelajaran sehingga kompetensi lambang bilangan khususnya dalam mengenal lambang bilangan 1-10 dapat meningkat. Berdasarkan pemaparan tersebut, maka dilakukan penelitian tindakan kelas dengan judul "Peningkatan kemampuan mengenal lambang bilangan melalui permainan kartu angka bagi anak kelompok A di Taman Kanak-kanak Negeri Pembina Bantul Semester II Tahun Ajaran 2018/2019". 


\section{METODE}

Penelitian ini termasuk Penelitian Tindakan Kelas (PTK). Menurut Wardhani (2010: 1-4), penelitian tindakan kelas adalah penelitian yang dilakukan oleh guru di kelasnya sendiri melalui refleksi diri dengan tujuan memperbaiki kinerjanya sehingga hasil belajar anak meningkat dan dilakukan dengan sistem siklus. Alur penelitian tindakan kelas dapat dilihat seperti Gambar 1.

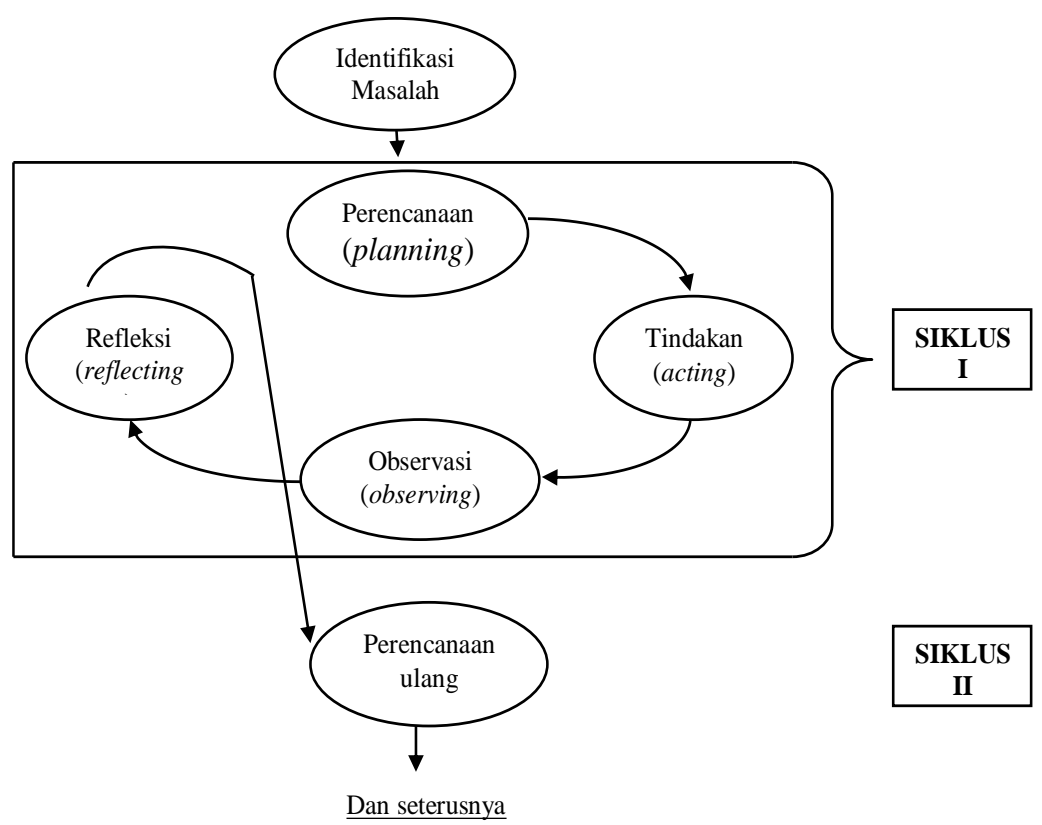

Gambar 1. Alur Penelitian Tindakan Kelas

\section{HASIL DAN PEMBAHASAN}

\section{Hasil}

\section{Pratindakan}

Pembelajaran mengenal keaksaraan awal khususnya lambang bilangan atau angka 1 - 10 pada kelompok A2 sebenarnya sudah cukup baik, tapi sebagian besar anak masih mengalami kesulitan dalam mengenal angka-angka tersebut. Hal ini terlihat saat anak melaksanakan kegiatan menjodohkan benda dengan angka yang sesuai, memberi tanda $>$ atau $<$, mengurutkan angka $1-10$. Sebelum melaksanakan penelitian tindakan kelas di kelompok A2 TKNegeri Pembina Bantul, peneliti melakukan Pratindakan penelitian untuk memperoleh data awal. Pelaksanaan Pratindakan dilaksanakan dengan menggunakan teknik pengumpulan data observasi, menggunakan lembar observasi setiap anak. Kemampuan mengenal lambang bilangan anak kelompok A2 di TK Negeri Pembina Bantul dari 20 anak hanya 5 anak yang mampu mengenal lambang bilangan atau $25 \%$ dari keseluruhan jumlah anak. Berdasarkan data observasi pada anak kelompok A2 di TK Negeri Pembina Bantul, maka peneliti berusaha mencari solusi dan melakukan perbaikan saat kegiatan mengenal keasaraan awal. Hal ini dimaksudkan supaya kemampuan lambang bilangan dalam menghubungkan lambang bilangan dengan benda-benda 1-10 dapat meningkat. Peneliti ingin meningkatkan kemampuan mengenal lambang bilangan menggunakan kartu angka.

\section{Siklus I}

\section{Perencanaan}

Perencanaan tindakan disusun meliputi perencanaan pembelajaran berupa Rencana Pelaksanan Pembelajaran Harian (RPPH), persiapan bahan dan alat untuk kegiatan mengenal lambang bilangan dan membuat lembar penilaian observasi kegiatan pembelajaran mengenal lambang bilangan pada anak. 
Rencana pelaksanaan pembelajaran terdiri dari dua pertemuan, yaitu pertemuan pertama pada hari Kamis tanggal 21 Februari 2019 dan pertemuan kedua pada hari Senin tanggal 25 Februari 2019 dengan membahas tema Alam Semesta dengan sub tema Gejala Alam/Gunung Meletus dilaksanakan di sudut Matematika dengan menghubungkan gambar gunung meletus dengan kartu angka, pada pertemuan kedua masih dilaksanakan di sudut Matematika menggunakan kartu angka dengan memberi kartu angka pada gambar gunung meletus dan meniru menuliskan angkanya. Perencanaan selanjutnya yang dilakukan peneliti pada Siklus I adalah menyiapkan media yaitu kartu angka dan Lembar Kegiatan Anak (LKA) serta instrumen untuk pengumpulan data berupa lembar observasi. Guru juga mempersiapkan dokumentasi anak saat kegiatan mengenal lambang bilangan dan saat guru melaksanakan proses kegiatan pembelajaran untuk mendukung penelitian, menyiapkan lembar observasi untuk mencatat proses kegiatan mengenal lambang bilangan dan untuk mengetahui kemampuan anak saat proses pembelajaran.

\section{Pelaksanaan}

Pertemuan pertama dilaksanakan pada hari Kamis tanggal 21 Februari 2019 untuk kemampuan lambang bilangan dengan permainan kartu angka, dengan menghubungkan gambar gunung meletus dengan kartu angka. Anak melaksanakan kegiatan menghubungkan gambar gunung dengan kartu angka untuk mengetahui kemampuan lambang bilangan. Adapun hasil kegiatannya adalah sebagai berikut:

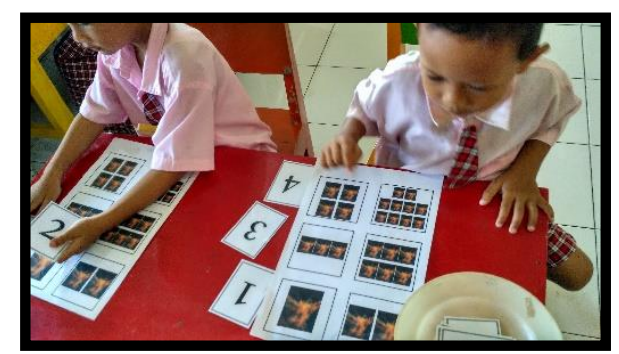

Gambar 2. Anak sedang melakukan kegiatan belajar mengajar menghubungkan gambar gunung dengan kartu angka

Pertemuan kedua dilaksanakan pada hari Senin tanggal 25 Februari 2019 untuk kemampuan lambang bilangan melalui permainan kartu angka dengan kegiatan memberi angka pada gambar gunung meletus dengan kartu angka sesuai jumlahnya.

Guru menjelaskan kegiatan yang akan dilaksanakan pada hari itu di sudut matemamatika memberi angka pada gambar gunung meletus dengan kartu angka sesuai jumlahnya. Adapun hasil kegiatan sebagai berikut.

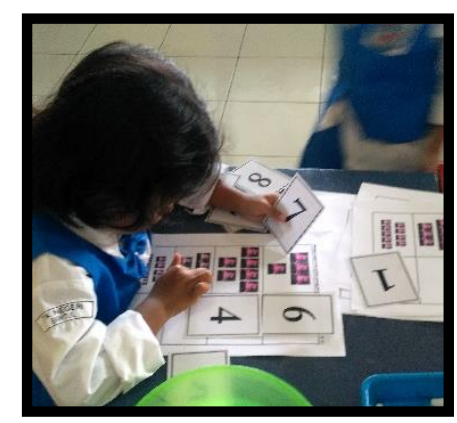

Gambar 3. Anak sedang menghubungkan gambar gunung dengan kartu angka

\section{Observasi}

Berdasarkan hasil pengamatan yang dilakukan anak dalam pembelajaran diketahui bahwa kemampuan lambang bilangan melalui menghubungkan gambar dengan angka pada Siklus I berjalan dengan baik. Dari 19 anak, 1 anak berada pada kriteria BSB, 5 anak berada pada kriteria BSH, 9 anak berada pada kriteria MB, dan 4 anak berada pada kriteria BB. Sebagian anak tampak bersemangat dan 
gembira dalam mengikuti pembelajaran dengan menggunakan kartu angka. Hal itu membuat anak semakin tertarik mengikuti kegiatan mengenal angka 1-10. Hal itu dikarenakan anak tidak memiliki konsentrasi yang baik pada saat diberi penjelasan oleh guru, anak terlihat konsentrasi tetapi anak saat mengerjakan kegiatan anak tidak bisa, beberapa anak masih bercakap-cakap dengan teman sebelahnya, sehingga mengakibatkan anak mengalami kesulitan dalam mengerjakan tugas. Sebagian anak juga belum menunjukkan sikap tanggung jawab terhadap tugas yang diberikan dalam membilang atau menghubungkan gambar dengan bilangan karena terbiasa dibantu.

Tabel 2. Penilaian kemampuan keaksaraan awal berupa lambang bilangan pada Siklus I

\begin{tabular}{|c|c|c|c|}
\hline \multirow[b]{2}{*}{ No } & \multirow[t]{2}{*}{ Kriteria } & \multicolumn{2}{|c|}{ Hasil Pengamatan } \\
\hline & & Jumlah Anak & Persentase \\
\hline 1 & BSB & 1 & $5,26 \%$ \\
\hline 2 & BSH & 5 & $26,32 \%$ \\
\hline 3 & MB & 9 & $47,37 \%$ \\
\hline 4 & BB & 4 & $21,05 \%$ \\
\hline
\end{tabular}

Dari Tabel 2 dapat dilihat perhitungan hasil pengamatan kemampuan lambang bilangan anak dalam menghubungkan benda dengan angka 1-10 baru mencapai 6 anak $(31,58 \%)$ yang berada apada kriteria BSH dan BSB, dan masih ada 13 anak $(64,42 \%)$ yang berada pada kriteria MB dan BB. Dengan hasil belajar pada Siklus I yang dianggap belum memenuhi kriteria/indikator keberhasilan sebesar 76\%, maka penelitian tindakan dilanjutkan pada Siklus II.

\section{Refleksi}

Berdasarkan hasil pengamatan yang dilakukan atas sikap anak dalam pembelajaran diketahui bahwa kemampuan keaksaraan awal dalam mengenal angka atau lambing bilangan 1-10 pada Siklus I berjalan dengan baik. Meskipun sebagian besar anak antusias dalam mengikuti proses pembelajaran, namun demikian kemampuan anak masih sangat kurang. Hal ini dapat dilihat dari hasil pengamatan bahwa ada 4 anak yang berada pada kriteria BB, dan 9 anak yang berada pada kriteria MB. Hal itu dikarenakan anak tidak memiliki konsentrasi yang baik pada saat diberi penjelasan oleh guru, anak bercakap-cakap dengan teman sebelahnya, dan sikap tanggung jawab terhadap tugas yang diberikan dalam mengenal lambang bilangan melalui kegiatan menghubungkan angka 1-10 karena terbiasa dibantu.

\section{Simpulan Siklus I dan Tindak Lanjut}

Dari hasil refleksi dapat disimpulkan pada Tabel 3 berikut ini.

Tabel 3. Simpulan Siklus I dan tindak lanjut Siklus II

Simpulan Siklus 1

Tindak Lanjut Siklus II

\begin{tabular}{lll}
\hline \hline $\begin{array}{l}\text { Anak bercakap-cakap dengan teman } \\
\text { saat diberikan penjelasan }\end{array}$ & $\begin{array}{l}\text { Guru menjelaskan dengan suara lebih } \\
\text { keras }\end{array}$ \\
\hline $\begin{array}{l}\text { Anak terbiasa dibantu saat } \\
\text { mengerjakan tugas }\end{array}$ & $\begin{array}{l}\text { Guru dalam menjelaskan kepada anak } \\
\text { lebih diperjelas }\end{array}$ \\
\hline
\end{tabular}




\section{Siklus II}

\section{Perencanaan}

Perencanaan tindakan disusun meliputi perencanaan pembelajaran berupa Rencana Pelaksanan Pembelajaran Harian (RPPH), persiapan bahan dan alat untuk kegiatan mengenal keaksaraan awal dan membuat lembar penilaian observasi kegiatan pembelajaran mengenal keaksaraan awal berupa lambang bilangan atau angka pada anak. Rencana pelaksanaan pembelajaran tediri dari dua pertemuan, yaitu pertemuan pertama pada hari Jumat tanggal 8 Maret 2019 dan pertemuan kedua pada hari Sabtu tanggal 9 Maret 2019 dengan membahas tema Negara dengan sub tema Tanah Air/Kota dilaksanakan di sudut Matematika dengan menghubungkan gambar kota/mall dengan kartu angka, pada pertemuan kedua masih dilaksanakan di sudut Matematika menggunakan kartu angka dengan membilang gambar kereta api dan memberi angka menggunakan kartu angka. Perencanaan selanjutnya yang dilakukan peneliti pada Siklus II adalah menyiapkan media yaitu kartu angka dan LKA, serta instrumen untuk pengumpulan data berupa lembar obervasi, dan mempersiapkan dokumentasi anak saat kegiatan mengenal lambang bilangan dan saat guru melaksanakan proses kegiatan pembelajaran untuk mendukung penelitian, menyiapkan lembar observasi untuk mencatat proses kegiatan mengenal lambang bilangan dan untuk mengetahui kemampuan anak saat proses pembelajaran.

\section{Pelaksanaan}

Pertemuan pertama dilaksanakan pada hari Jumat tanggal 8 Maret 2019 untuk kemampuan lambang bilangan dengan permainan kartu angka. Guru menjelaskan kegiatan yang akan dilaksanakan pada hari itu, di sudut matematika anak menghubungkan gambar mall dengan kartu angka yang sesuai.
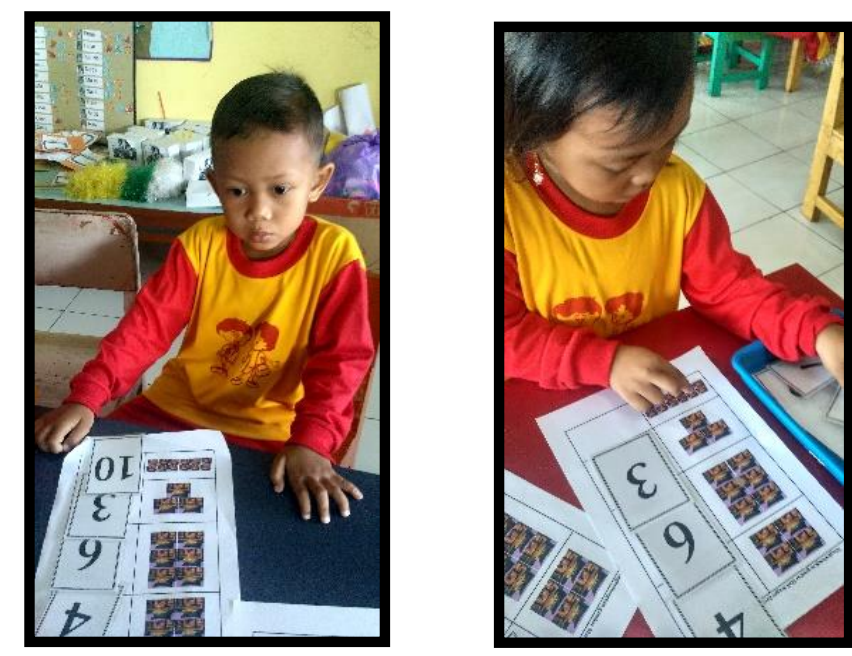

Gambar 4. Anak sedang menghubungkan jumlah gambar mall dengan kartu angka

Pertemuan kedua dilaksanakan pada hari Sabtu tanggal 09 Maret 2019, untuk kemampuan lambang bilangan melalui permainan $k$ artu angka hari ini anak-anak akan diajak membilang gambar kereta api. Anak melaksanakan kegiatan membilang dan memberi kartu angka pada gambar kereta api untuk mengetahui peningkatan kemampuan lambang bilangan guru dan kolaborator mencatat pada lembar observasi, selanjutnya akan dipaparkan pada kegiatan berikut. 
Jurnal Pendidikan Anak, Volume 9 (2), Tahun 2020

Sri Sumarsih

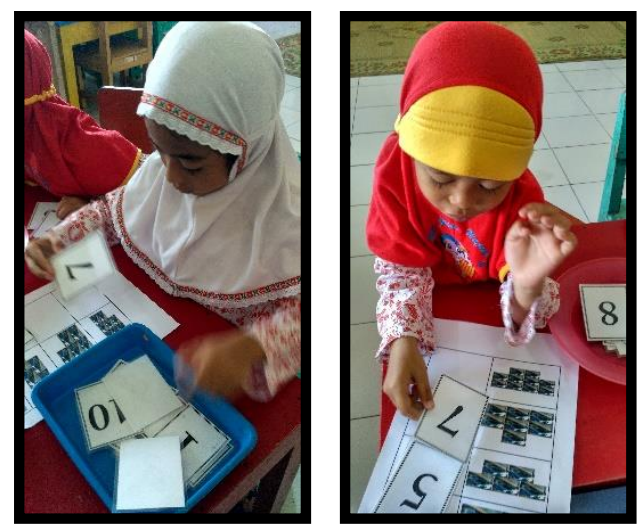

Gambar 5. Anak sedang membilang dan memberi kartu angka pada gambar kereta api

\section{Observasi}

Berdasarkan pengamatan yang dilakukan anak dalam pembelajaran diketahui bahwa kemampuan lambang bilangan melalui menghubungkan gambar dengan angka pada Siklus II berjalan dengan baik. Hal ini tampak dari sebagian besar anak antusias mengikuti pembelajaran dari pada biasanya, dan dalam proses pembelajaran tampak adanya peningkatan kemampuan lambang bilangan. Dari 19 anak, terdapat 7 anak yang beada pada kriteria BSB, 10 anak yang berada pada kriteria BSH, 2 anak yang berada pada kriteria MB dan tidak ada anak yang berada pada kriteria BB.

Tabel. 3 Penilaian kemampuan keaksaraan awal berupa lambang bilangan pada Siklus II

\begin{tabular}{|c|c|c|c|}
\hline \multirow[b]{2}{*}{ No } & \multirow[t]{2}{*}{ Kriteria } & \multicolumn{2}{|c|}{ Hasil Pengamatan } \\
\hline & & Jumlah Anak & Persentase \\
\hline \multirow[b]{2}{*}{1} & BSB dan BSH & & \\
\hline & & 7 & $36,84 \%$ \\
\hline \multirow{3}{*}{2} & $\mathrm{BSH}$ & & \\
\hline & & 10 & $52,63 \%$ \\
\hline & MB & & \\
\hline \multirow[t]{2}{*}{3} & & 2 & $10,53 \%$ \\
\hline & BB & & \\
\hline \multirow[t]{2}{*}{4} & & 0 & $0 \%$ \\
\hline & Jumlah & 19 & $100 \%$ \\
\hline
\end{tabular}

Dari Tabel 3 dapat dilihat perhitungan hasil pengamatan kemampuan lambang bilangan anak dalam mennghubungkan benda dengan angka 1-10 mencapai 17 anak $(89,47 \%)$ berada pada kriteria BSH dan BSB, serta 3 anak (10,53\%) berada pada kriteria MB. Dengan hasil belajar pada Siklus II yaitu sejumlah $89,47 \%$, dan telah mencapai indikator keberhasilan, maka penelitian tindakan dihentikan. 


\section{Refleksi}

Berdasarkan hasil pengamatan yang dilakukan atas sikap anak dalam pembelajaran diketahui bahwa kemampuan keaksaraan awal dalam mengenal angka 1 - 10 pada Siklus II berjalan dengan baik. Terlihat sebagian besar anak antusias mengikuti pembelajaran daripada biasanya, dan dalam proses pembelajaran tampak adanya peningkatan kemampuan membentuk. Dari 19 anak, 7 anak berada pada kriteria BSB sejumlah 7 anak, 10 anak berada pada kriteria BSH, 2 anak berada pada kriteria MB, dan tidak ada anak yang berada pada kriteria BB.

Hasil evaluasi dan hasil diskusi antara guru dengan kolaborator yaitu ada beberapa hal yang dapat direfleksikan ke dalam tindakan selanjutnya, agar pelaksanaan proses pembelajaran kemampuan lambang bilangan melalui permainan kartu angka dengan menghubungkan gambar dengan angka $1-10$ di Kelompok A2 TK Negeri Pembina Bantul dapat lebih meningkat lagi kualitas pembelajarannya. Pada dasarnya, proses pembelajaran pada Siklus II ini mengalami peningkatan daripada Siklus sebelumnya. Hasil pengamatan pada Siklus I menunjukkan kemampuan lambang bilangan anak mencapai 31,58\% baru 6 anak yang telah mencapai Berkembang Sangat Baik dan Berkembang Sesuai Harapan. Sedangkan pada Siklus II Kemampuan mengenal lambang bilangan anak mencapai 89, 47 \% berarti 17 anak yang telah mencapai Berkembang Sangat Baik dan Berkembang Sesuai Harapan. Dengan demikian kemampuan anak dalam mengenal lambang bilangan di Kelompok A2 TK Negeri Pembina Bantul menunjukkan peningkatan sebesar 57,89\%. Oleh karena itu dapat disimpulkan bahwa hasil belajar anak telah melebihi indikator/target keberhasilan yang telah ditetapkan di awal yaitu sebesar 76\%, sehingga penelitian tindakan dihentikan.

\section{Pembahasan}

Berdasarkan hasil Siklus I dan Siklus II maka diketahui bahwa pada akhir siklus terjadi peningkatan pada aspek yang diamati. Hal ini dapat dilihat pada Tabel 4.

Tabel 4. Kemampuan mengenal keaksaraan awal lambang bilangan pada Siklus I dan Siklus II

\begin{tabular}{lcc}
\hline \multicolumn{1}{c}{ Kriteria Kemampuan Anak } & Siklus I & Silkus II \\
\hline \hline Berkembang Sangat Baik & & $36,84 \%$ \\
\hline Berkembang Sesuai Harapan & $26,32 \%$ & $52,63 \%$ \\
\hline Mulai Berkembang & $47,37 \%$ & $10,53 \%$ \\
\hline Belum Berkembang & $21,05 \%$ & - \\
\hline
\end{tabular}

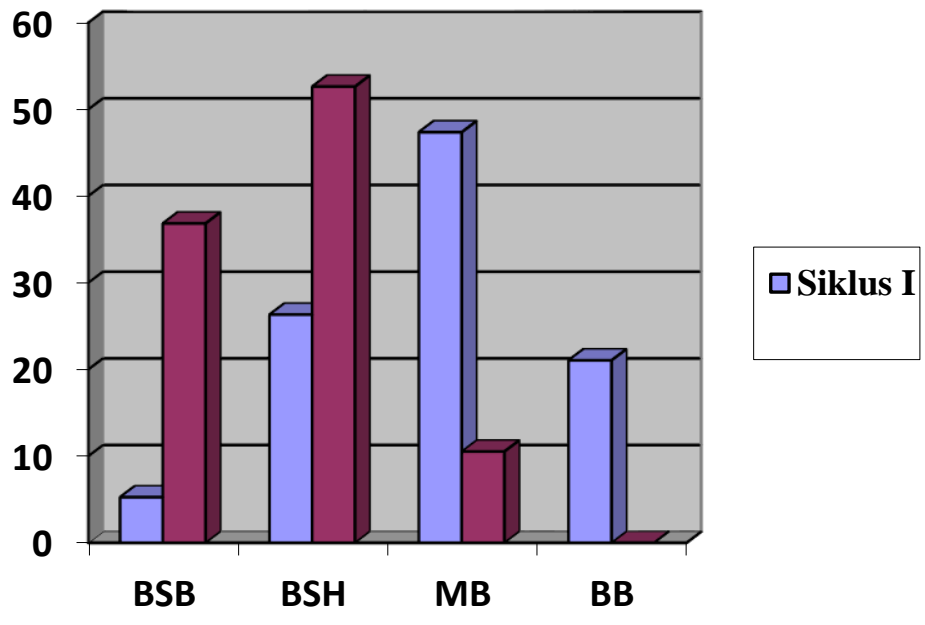

Grafik 1. Kemampuan keaksaraan awal berupa lambang bilangan pada Siklus I dan Siklus II

Dengan memperhatikan Tabel 4 tentang kemampuan mengenal lambang bilamgan melalui permainan kartu angka dengan menghubungkan benda- benda dengan angka 1-10 di Kelompok A2 TK Negeri Pembina Bantul dari Siklus I dan Siklus II adalah: 
Kemampuan anak yang berada pada kriteria BSB (Berkembang Sangat Baik) dan BSH (Berkembang Sesuai Harapan) yang semula 6 anak atau 31,58 \% pada Siklus I menjadi 17 anak yang berada pada kriteria berkembang sangat baik dan berkembang sesuai harapan atau 89,47\% pada Siklus II. Artinya mengalami peningkatan sejumlah 57,89\%. Kemampuan anak dalam mengenal lambang bilangan yang berada pada kriteria MB (Mulai Berkembang) dan BB (Belum Berkembang) pada Siklus I $68 \%$ menjadi $10,53 \%$. Artinya mengalami penurunan sebesar 57,47\%.

Lebih lanjut, untuk lebih jelasnya dapat dilihat pada Tabel 5 berikut ini.

Tabel 5. Persentase peningkatan kemampuan mengenal lambing bilangan

\begin{tabular}{lccc}
\hline $\begin{array}{l}\text { Kriteria Kemampuan } \\
\text { Anak }\end{array}$ & Siklus I & Siklus II & Peningkatan Kemampuan \\
\hline $\begin{array}{l}\text { Berkembang Sangat } \\
\text { Baik }\end{array}$ & $5,26 \%$ & $36,84 \%$ & $31,58 \%$ \\
\hline $\begin{array}{l}\text { Berkembang Sesuai } \\
\text { Harapan }\end{array}$ & $26,32 \%$ & $52,63 \%$ & $26,31 \%$ \\
\hline Mulai Berkembang & $47,37 \%$ & $10,53 \%$ & $-36,84 \%$ \\
\hline Belum Berkembang & $21,05 \%$ & $0 \%$ & $-21,05 \%$ \\
\hline
\end{tabular}

Dengan demikian dapat disimpulkan bahwa "kemampuan mengenal lambang bilangan di kelompok A2 Taman Kanak-kanak Negeri Pembina Bantul menunjukkan peningkatan". Peningkatan ini terjadi karena anak lebih bersemangat saat mengikuti kegiatan mengenal keaksaraan awal dengan menggunakan kartu angka.

\section{SIMPULAN}

Hasil penelitian menunjukkan bahwa kemampuan keaksaraan awal berupa mengenal lambang bilangan dapat ditingkatkan melalui permainan kartu angka. Hal ini ditunjukkan pada jumlah anak yang berada pada kriteria Berkembang Sesuai Harapan (BSH) dan Berkembang Sangat Baik (BSB) mengalami peningkatan $57,89 \%$. Adapun langkah-langkahnya yaitu: guru menyiapkan kartu angka dan lembar kegiatan anak, anak mengambil lembar kegiatan dan kartu angka, anak bermain kartu angka dengan memilih dan menghubungkan gambar yang ada dalam lembar kegiatan dengan lambang bilangannya, dan anak mengkomunikasikan hasil menghubungkan gambar dengan kartu angka pada guru.

\section{UCAPAN TERIMA KASIH}

Terima kasih peneliti ucapkan kepada pihak sekolah yang sangat membantu proses dari awal hingga penyelesaian penelitian ini dan tak lupa kepada teman-teman yang saling mendukung dan memberi semangat kepada peneliti. 
Jurnal Pendidikan Anak, Volume 9 (2), Tahun 2020

Sri Sumarsih

\section{DAFTAR PUSTAKA}

Anggoro, dkk. (2011). Metode penelitian. Jakarta: Universitas Terbuka.

Arikunto, S. (2011). Penelitian tindakan. Yogyakarta: Aditya Madia.

Fatimah. (2009). Fun math matematika asyik dengan metode pemodelan. Bandung: DAR Mizan.

Kementerian Pendidikan dan Kebudayaan. (2015). 10 pedoman penerapan kurikulum 2013. Kementrian Pendidikan dan Kebudayaan. Jakarta.

Kementerian Pendidikan dan Kebudayaan. (2015). Permendikbud No 146 tahun 2014. Kementerian Pendidikan dan Kebudayaan. Jakarta.

Sujiono, Y.N. (2017). Metode pengembangan kognitif. Jakarta: Universitas Terbuka.

Suryadin dan Rostini. (2011). Pengembangan profesi guru. penelitian tindakan kela. Bandung: CV Amalia Book.

Suryana. (2016). Pendidikan anak usia dini stimulasi dan aspek perkembangan anak. Jakarta: Kencana.

Mursid. (2015). Belajar dan pembelajaran PAUD. Bandung: PT Remaja Rosdakarya.

Nusa, P dan Lastari, N.D. (2012). Penelitian kreatif pendidikan anak usia dini. Jakarta: PT Raja Grafindo

Persada.

Zulkifli. (1997). Psikologi perkembangan. Bandung: CV Remaja Karya. 